\title{
サービス付き高齢者向け住宅の整備方針確立に向けた基礎的研究 A FUNDAMENTAL STUDY TOWARDS ESTABLISHING A GUIDING PRINCIPLE ON DEVELOPING ELDERLY HOUSING WITH LIFE SUPPORT SERVICE
}

\author{
佐 藤栄 治*, 井上由起子**, 生田京子***
}

\author{
Eiji SATOH, Yukiko INOUE and Kyoko IKUTA
}

\begin{abstract}
In this study, based on the statistical data and future estimates, the number of the elderly who are likely to use elderly housing with life support service ("elderly" hereinafter is used in this context) in 2025 was calculated, and the derivation method of basis for estimating the quantity of elderly housing needed to be constructed or improved was demonstrated as an essay. In addition, by specifying the minimum living expense in case of living in elderly housing and by comparing this figure to the data of income levels used as bases for determining premiums for long-term care insurance, the balance between the number of elderly housing in need for public financial support, such as housing benefit or construction aid, and the number of the same deemed possible to be developed in the market was examined. The trial calculations in this study were made with the cooperation of 7 local municipalities, most of which are in the Tokyo metropolitan area that is supposed to have high demand for elderly housing.

The result showed that, as elderly people's situation is greatly different area to area, it is necessary to establish a standard on elderly housing construction and improvement on a municipality-by-municipality basis taking into account the local circumstance of each area.
\end{abstract}

Keywords: elderly housing with life support service, user forcast, the style of family unit and housing, regional difference サービス付き高齢者向け住宅, 利用者推計, 世帯・住宅類型, 地域格差

\section{1. 背景と目的}

我が国では，中重度者向けの住まい（介護保険施設，認知症高齢 者グループホーム，特定施設等；以下高歯者施設）に比べて軽中度 者向けの住まい（生活支援サービス付き高専賃，ケアハウスなど； 以下高齢者住宅）の整備が遅れている。これを踏まえ, 国はサービ ス付き高齢者向け住宅の整備に向けた施策展開に着手した注 1 )。サー ビス付き高龄者向け住宅の特徵は，1賃貸借契約に基づくバリアフ リー対応の集合住宅，(2)安否確認・緊急時対応・生活相談なぞの生 活支援サービスを附帯，(3)多くの事例で食事サービスを附帯（ただ し利用の選択権は居住者にある), (4)介護サービスや医療サービスは 個々の利用者の意向や状態像に応じて, 建物に併設された事業所や 地域の事業所のサービスを組み合わせて利用，の4 点にある。これ らが保障されることで, 高齢者施設と比べて安心を備えつつも自由 度が高い暮らしが実現可能とされている。

自立支援，介護人材の有効活用，地域包括ケアの確立などの観点 からみて, このような高齢者住宅の整備が必要であることに疑いの 余地はないが, 必要な整備戸数はどれくらいなのか, 必要性の高い 高齢者がどれくらい存在するのか, 現行の仕組みで利用者の支払い 能力と事業者の安定経営が両立しうるのか, 国や地方公共団体の財 政的支援はどの程度必要なのかについては明確な指針は示されてい ない.この理由としては以下の二点が考えられる.
一つには，高齢者住宅の整備が緒についたばかりであるため，事 例的研究は散見されるものの, 高齢者住宅の全体像を見通すために 必要不可欠な住宅政策と福祉政策をまたがるような研究蓄積が極め て少ないことによるものである注 2)。二つには，他国の高㱓者住宅 整備割合は検討材料としては参考になりうるが，そのまま我が国の 制度設計に当てはめることが困難なことによるものである注 3 ). こ の点は高齢者施設の整備割合が諸外国でほぼ同じ值に収斂しつつあ るのと大きく異なる。高齢者施設への転居は，家族介護の負担の大 きさから住宅や世帯の状況に大きく左右されることなく中重度高㱓 者に一定の割合で発生すると考えられており, 我が国でも他国の值 を参考に整備床数（参酌標準と呼ぶ）を設定している注4)。これに対 し, 高歯者住宅については住宅政策, 世帯構成, 住宅の所有や転居に 対する意識が国によって大きく異なるため, 他国の值をそのまま援 用することは適切ではない. 加えて, 高齢者施設と異なり, 同じ要 介護度でも住宅や世帯の状況によって高齢者住宅への転居意向は大 きく異なると推察される。

以上の理由から, 我が国独自の視点を加味したうえで高齢者住宅 の目標整備戸数を算出することは, その必要性は認めつつも, 現時 点では推測に基づく部分が多く拙速であると考える。一方で，各種 統計情報をもとに高歯者住宅を利用する可能性が高い高歯者数（以 下，対象高齢者，定義は後述）を試算することは可能であり，この
* 宇都宮大学大学院工学研究科地球環境デザイン学専攻 助教. 博士 (工学)

国立保健医療科学院医療・福祉サービス研究部 客員研究員

** 国立保健医療科学院医療・福祉サービス研究部 上席主任研究官・博士 (工学)

*** 名城大学理工学部建築学科 准教授 ·博士 (工学)
Assistant Prof., Graduate School of Engineering, Utsunomiya Univ., Dr. Eng.

Visiting Fellow, Department of Management Science, National Institute of Public Health Senior Research Fellow, Department of Health Services, National Institute of Public Health, Dr. Eng.

Assoc. Prof., Faculty of Science and Engineering, Meijo Univ., Dr. Eng. 
試算を出発点に議論を重ねることが妥当と考える、そこで本研究で は, 以下の 4 点に留意しつつ対象高歯者数を試算するとともに, 今 後の高齢者住宅の整備指針構築に向けた課題を抽出することを試み た.

(1)市町村単位（含む特別区）で対象高歯者数の試算を行う。高齢者 住宅は建物内でサービスが完結する仕組みではないため, 福祉政策・ 住宅政策・まちづくり政策との関連性が強く問われること，介護保 険の保険者単位と合致していることなどから市町村単位で整備方針 を策定することが適切である。

(2)住宅の状況と世帯の状況によって高齢者住宅への転居ニーズは異 なると推察されることから,住宅の状況（持ち家・公的賃貸・民間賃貸） $\times$ 世帯の状況（単身・夫婦のみ・その他等）の 9 類型で, 対象高齝 者数を試算する注 ${ }^{5)}$.

(3) 2025 年を推計年に設定した. 2025 年は団塊の世代が後期高齢者 になりきる年である，後期高齢者は要介護認定の出現率が高まるこ とから, 厚生労衝省は 2025 年を視野に施策を展開している注 6).

(4)高齢者住宅で生活する場合の最低生活費を算出し，これに高齢者 の所得状況を加味して検討を行う注 7 ）。これにより財政支援（住宅 扶助や建設補助）すべき高齢者住宅数と市場で整備可能な高齢者住 宅数のバランスを検討できる.

\section{2. 研究方法}

2. 1 分析の概要

対象高齢者数とは, 要介護 1 以上の高齢者数からその市町村で整 備されている高齢者施設の床数を除した数と定義する。そのうえで 以下の二つの試算を行った。

(1)対象高齢者数の算定（図 1 )

人口推計值 (2025 年推計值), 要介護認定者数 (現状值), 世帯の 状況 (単身・夫婦のみ・その他の構成比 : 2025 年推計值), 住宅の 状況（持ち家・公的賃貸・民間賃貸の構成比：現状値），の 4 種の統 計情報から対象高齢者となりうる人数を推計した。その值から対象 市町村の高歯者施設定員数 (後述) を減算し, 対象高齡者数を算定 した.

(2)高齢者住宅における最低生活費と支払い能力（図 2)

既報注 8 ）で算出したエリア別の高歯者住宅家顀を基に算出した当 該自治体の高歯者住宅家顀（後述）と生活保護の生活扶助費（後述） を合算した額を算出し，こ扎を最低生活費と定義する。この最低生 活費を介護保険料算定時の所得段階デー夕と比較する.

\section{2 対象自治体}

今後高歯化が急激に進む首都圈を中心に 7 つの市町村（含む特別 区）を対象とした。各対象自治体の特性と調査により取得した基礎 デー夕は以下の通り（表 1 ).

A区 東京都特別区 : 都心三区を取り囲む区の一つ

B市 東京都ベッドタウン：1970 年代に開発されたベッドタウン

C市 埼玉県ベッドタウン：1960 年代に開発されたベッドタウン

D市 関東圈県庁所在地 : 北関東に位置する県庁所在地

$\mathrm{E}$ 市 東海近畿圏県庁所在地 : 三大都市圏に位置する県庁所在地

$\mathrm{F}$ 市 地方小都市 : 九州地方の人口 10 万人強の人口減少進行都市

$\mathrm{G}$ 市 地方農村都市 : 九州地方の人口 6 万人弱の人口減少進行都市

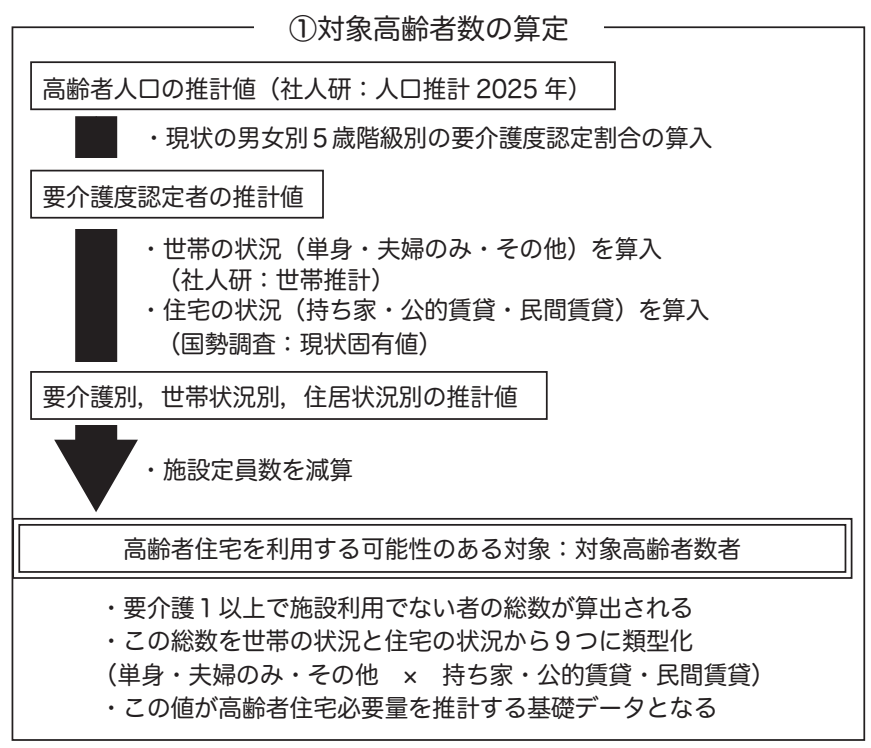

図 1 対象高齢者数の算定手順 (2)最低生活費と支払い能力

\section{高専賃に入居した場合の最低生活費を算出 \\ 生活保護制度による生活扶助基準額 \\ (70 歳以上単身，地域類型を考慮） \\ $+$}

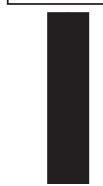

既報および対象地域の平均市場家賃から推計した 当該自治体の高專賃家賃

\section{所得分布を把握}

介護保険料算定時の所得段階を活用（6段階に統一） (調查対象自治体提供デー夕)

\begin{tabular}{|c|}
\hline 整備費補助・家貨補助の必要性の検討 \\
\hline 財政支援すべき高齢者住宅と市場に委ねられる高齢者住宅の \\
バランスを検討
\end{tabular}

図2 高歯者住宅における最低生活費と支払い能力の算定手順

\section{3 対象高齢者数の算定手順と結果}

算定手順を(1)〜 (6)に示す。また算定に用いた各種指標を表 1 〜表 3 に示す。

\section{1 算定手順}

\section{(1)人口推計値}

国立社会保障・人口問題研究所が広く公開している「日本の市区 町村別将来推計人口」を用いて高齢者人口の将来推計值 (2025 年) を収集した。

\section{(2)要介護認定者数の推計}

調査対象自治体の協力を得て, 男女別年歯階級別（5歳階級別） の要介護認定率（現状值）を把握した。例としてA区とG市の認定 率を表 3 に示す。男女別，年齢階級別で認定率が大きく異なること が分かる、本稿では精緻な推計を行うため, 上記の男女別年龄階級 別の認定率を用いた，現状の認定率が将来にわたつて継続すると仮 定し人口推計值（2025 年時点）と乗算することで算出した。要介護 認定率データの提供年月は調査対象自治体によって異なる（2009 年 3 月〜 2009 年 12 月).

調査対象 7 自治体のうち, D市は男女別なしの要介護認定率， E 
表 1 調査対象地域の基礎デー夕（調査時の現状值）

\begin{tabular}{|c|c|c|c|c|c|c|c|c|c|}
\hline & & & A区 & B市 & C市 & D市 & E市 & F市 & G市 \\
\hline \multirow{8}{*}{$\begin{array}{l}\text { 人 } \\
\text { 口 } \\
\text { 等 }\end{array}$} & 人口 & 総人口（人） & 345,413 & 145,673 & 158,571 & 504,534 & $2,247,752$ & 126,952 & 60,633 \\
\hline & & 高齢者人口（人） & 65,954 & 29,315 & 31,784 & 95,074 & 451,930 & 37,434 & 17,591 \\
\hline & & 高齢化率（\%） & 19.09 & 20.12 & 20.04 & 18.84 & 20.11 & 29.49 & 29.01 \\
\hline & 要介護度認定者数 & & 9,631 & 3,279 & 3,596 & 13,843 & 70,733 & 6,650 & 3,434 \\
\hline & 要介護度認定率 & 65歳以上（\%） & 14.60 & 11.19 & 11.31 & 14.56 & 15.65 & 17.76 & 19.52 \\
\hline & & 65-74歳（\%） & 4.47 & 3.42 & 3.21 & 3.72 & - & 4.11 & 3.52 \\
\hline & & 75-84歳（\%） & 18.82 & 16.14 & 17.03 & 18.52 & - & 18.55 & 22.38 \\
\hline & & 85歳- (\%) & 49.75 & 50.52 & 50.90 & 55.43 & - & 54.49 & 68.90 \\
\hline \multirow{4}{*}{$\begin{array}{l}\text { 世 } \\
\text { 帯 }\end{array}$} & 高齢者世帯数（七 & & 45,604 & 15,488 & 18,028 & 52,291 & 282,404 & 24,222 & 11,619 \\
\hline & 世帯構成比 & 単身世帯割合（\%） & 34.37 & 24.22 & 19.09 & 20.69 & 28.14 & 29.83 & 26.92 \\
\hline & & 夫婦のみ世帯（\%） & 17.87 & 18.93 & 18.10 & 10.32 & 18.95 & 17.84 & 20.68 \\
\hline & & その他（\%） & 47.77 & 56.86 & 62.80 & 68.99 & 52.91 & 52.33 & 52.40 \\
\hline \multirow{3}{*}{$\begin{array}{l}\text { 住 } \\
\text { 宅 }\end{array}$} & 高齢者世帯に占女 & 率 (\%) & 71.77 & 63.38 & 86.49 & 86.30 & 69.22 & 79.86 & 94.12 \\
\hline & 同民間賃貸率（（） & & 19.13 & 5.43 & 7.29 & 9.47 & 15.81 & 10.32 & 2.29 \\
\hline & 同公的賃貸住宅至 & & 6.82 & 30.50 & 5.58 & 3.47 & 14.13 & 8.77 & 3.09 \\
\hline \multirow{3}{*}{ 施 } & 第4 期後の高齢老 & 数（定員：人） & 1,593 & 1,219 & 1,431 & 4,216 & 21,260 & 1,857 & 821 \\
\hline & & 者人口整備割合（\%） & 3.73 & 3.88 & 3.98 & 4.17 & 4.29 & 4.87 & 4.50 \\
\hline & 参酎標準によった & 備数＊（定員：人） & 1,742 & 721 & 785 & 2,872 & 15,467 & 1,179 & 602 \\
\hline \multirow{4}{*}{$\begin{array}{l}\text { 所 } \\
\text { 得 }\end{array}$} & 6段階換算所得段 & 没階割合 (\%) & 31.01 & 25.31 & 20.46 & 25.93 & 29.38 & 42.92 & 47.16 \\
\hline & 同4段階割合（\% & & 22.46 & 27.67 & 33.17 & 33.49 & 26.80 & 26.03 & 28.61 \\
\hline & 同5段階割合（\% & & 23.11 & 22.94 & 25.29 & 25.01 & 36.35 & 22.40 & 17.85 \\
\hline & 同6段階割合（\% & & 23.42 & 24.08 & 21.08 & 15.58 & 7.47 & 8.65 & 6.38 \\
\hline
\end{tabular}

表2 調査対象地域の基礎データ（2025 年の推計値）

* 要介護度 2 5 の認定者に対して $37 \%$ の整備

\begin{tabular}{|c|c|c|c|c|c|c|c|c|c|}
\hline & & & A区 & B市 & C市 & D市 & E市 & F市 & G市 \\
\hline \multirow{4}{*}{$\begin{array}{l}\text { 人 } \\
\text { 等 }\end{array}$} & 人口推計値 & 総人口（人） & 330,314 & 143,216 & 139,807 & 501,668 & $2,162,709$ & 98,836 & 49,948 \\
\hline & & 高齢者人口（人） & 86,720 & 44,973 & 50,578 & 139,353 & 585,532 & 39,474 & 18,927 \\
\hline & & 高齢化率（\%） & 26.25 & 31.40 & 36.18 & 27.78 & 27.07 & 39.94 & 37.89 \\
\hline & 要介護度認定者数（人） & & 16,468 & 8,163 & 9,744 & 15,798 & 91,643 & 8,396 & 4,712 \\
\hline \multirow{6}{*}{$\begin{array}{c}\text { 世 } \\
\text { 帯 }\end{array}$} & a ：世帯推計の世帯構成比 & 単独世帯 & 25.46 & 25.46 & 17.69 & 14.92 & 17.22 & 19.47 & 19.61 \\
\hline & (平均：\%) & 夫婦のみ世帯 & 34.22 & 34.22 & 34.27 & 27.55 & 32.70 & 32.11 & 34.32 \\
\hline & & その他 & 40.32 & 40.32 & 48.04 & 57.52 & 50.08 & 48.42 & 46.07 \\
\hline & $b$ : 世帯推計+地域指標 & 単独世帯 & 22.89 & 22.89 & 12.58 & 10.53 & 13.81 & 17.55 & 16.79 \\
\hline & (平均：\%) & 夫婦のみ世帯 & 38.19 & 38.19 & 31.99 & 24.46 & 32.74 & 34.03 & 36.03 \\
\hline & & その他 & 38.92 & 38.92 & 55.43 & 65.01 & 53.45 & 48.42 & 47.18 \\
\hline \multirow{2}{*}{ 施 } & $a$ : 第4期後の水準整備数（ & （床数） & 3,232 & 1,746 & 2,014 & 5,816 & 25,148 & 1,922 & 852 \\
\hline & $\mathrm{b}$ : 参酌標準の整備数（床数 & & 3,062 & 1,824 & 2,186 & 3,242 & 20,040 & 1,538 & 857 \\
\hline
\end{tabular}

表3 A区と G市の要介護度認定者数と認定率

\begin{tabular}{|c|c|c|c|c|c|c|c|c|c|c|c|c|c|c|c|c|}
\hline & \multirow{2}{*}{$\begin{array}{l}\text { 年齢 } \\
\text { 階級 }\end{array}$} & \multicolumn{2}{|c|}{ 要支援 1} & \multicolumn{2}{|c|}{ 要支援2 } & \multicolumn{2}{|c|}{ 要介護 1} & \multicolumn{2}{|c|}{ 要介護 2} & \multicolumn{2}{|c|}{ 要介護 3} & \multicolumn{2}{|c|}{ 要介護4 } & \multicolumn{2}{|c|}{ 要介護 5} & \multirow{2}{*}{$\begin{array}{l}\text { 各階 } \\
\text { 級別 }\end{array}$} \\
\hline & & 男 & 女 & 男 & 女 & 男 & 女 & 男 & 女 & 男 & 女 & 男 & 女 & 男 & 女 & \\
\hline \multirow{6}{*}{$\begin{array}{l}\text { A } \\
\text { 区 }\end{array}$} & $65-69$ & 0.005 & "0.006 & (0.003 & 0.003 & "0.005 & "0.005 & "0.006 & 0.004 & 0.007 & (0.004 & 0.004 & (20.001 & "0.004 & "0.002 & 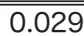 \\
\hline & $70-74$ & 0.008 & 0.017 & 0.010 & 0.010 & 0.011 & 0.013 & 0.009 & 0.008 & 0.010 & 0.008 & 0.006 & 0.004 & 0.005 & 0.006 & 0.062 \\
\hline & $75-79$ & 0.018 & 0.048 & 0.014 & 0.020 & 0.021 & 0.029 & 0.016 & 0.017 & 0.019 & 0.018 & 0.011 & 0.010 & 0.008 & 0.013 & 0.136 \\
\hline & $80-84$ & 0.032 & 0.082 & 0.025 & 0.033 & 0.035 & 0.063 & 0.026 & 0.036 & 0.031 & 0.045 & 0.015 & 0.023 & 0.014 & 0.030 & 0.263 \\
\hline & 85- & 0.074 & 0.081 & 0.046 & 0.054 & 0.062 & 0.096 & 0.059 & 0.069 & 0.070 & 0.105 & 0.036 & 0.067 & 0.029 & 0.072 & 0.498 \\
\hline & 各階級別 & 0.017 & 0.039 & 0.013 & 0.020 & 0.018 & 0.034 & 0.015 & 0.021 & 0.018 & 0.028 & 0.010 & 0.016 & 0.008 & 0.019 & 0.146 \\
\hline \multirow{6}{*}{$\begin{array}{c}\text { G } \\
\text { 市 }\end{array}$} & 65-69 & 0.002 & 0.002 & 0.003 & 0.004 & 0.002 & 0.002 & 0.006 & 0.005 & 0.003 & 0.001 & 0.002 & 0.002 & 0.002 & 0.004 & 0.020 \\
\hline & $70-74$ & 0.008 & 0.011 & 0.007 & 0.011 & 0.010 & 0.008 & 0.006 & 0.007 & 0.005 & 0.005 & 0.006 & 0.003 & 0.006 & 0.004 & 0.049 \\
\hline & $75-79$ & 0.012 & 0.037 & 0.016 & 0.046 & 0.022 & 0.030 & 0.021 & 0.019 & 0.019 & 0.011 & 0.011 & 0.016 & 0.015 & 0.011 & 0.148 \\
\hline & $80-84$ & 0.036 & 0.079 & 0.047 & 0.091 & 0.041 & 0.062 & 0.044 & 0.036 & 0.042 & 0.029 & 0.034 & 0.038 & 0.018 & 0.034 & 0.333 \\
\hline & 85- & 0.084 & 0.089 & 0.093 & 0.128 & 0.103 & 0.122 & 0.080 & 0.093 & 0.084 & 0.096 & 0.058 & 0.099 & 0.060 & 0.107 & 0.689 \\
\hline & 各階級別 & 0.018 & 0.039 & 0.021 & 0.050 & 0.024 & 0.039 & 0.022 & 0.028 & 0.020 & 0.025 & 0.015 & 0.027 & 0.014 & 0.027 & 0.195 \\
\hline
\end{tabular}


市は男女別なし年齢階級別なしの要介護認定率である。このため他 市の試算に比べて D市と E 市の試算は対象高齢者数が過小評価に なっているものと推察され, この点を踏まえて試算結果を読み込む 必要がある.

(3)世帯の状況（世帯構成）の算入

世帯構成によって高齢者住宅のニーズは異なると推測し, 高齢者 を含む世帯を単身・夫婦のみ・その他の 3 種に類型化した，高齢者 住宅には生活相談・緊急通報・安否確認などの生活支援サービスと 食事サービスが附帯されているが，これらサービスは本人の心身機 能が低下しても, 同居家族かいる場合には家族のシャドーワークと して提供されていることが多いこと, 夫婦のみ世帯の場合にはどち らが心身機能が低下したかによって必要度が異なること, 単身世帯 ではサービスを必要とする可能性が高いことを踏まえ, この 3 類型 とした. 3 類型の世帯構成比の算出方法は以下の 2 通りで行った.

a : 世帯推計の世帯構成比を使用（世帯推計）

社会保障・人口問題研究所が公開している「日本の世帯数の将来 推計 (都道府県別推計)」をもとに, 都道府県単位の世帯構成比を当 該自治体の值としてそのまま使用した。

$\mathrm{b}$ : 世帯推計の世帯構成比と現状構成比を使用（世帯推計+地域指標） 上記 a では道府県の世帯構成比をそのまま算入したのに対し, b では調査対象自治体の世帯構成比（2025 年推計值）を元に, 変化差 分 $(2005$ 年 $\rightarrow 2025$ 年の世帯構成比の差分）を年齢階級別に按分し たものを加算し，想定構成比を算出した。元デー夕には，2005 年の 国勢調査デー夕を用いた。

(4)住宅の状況（所有形態）の算入

世帯構成と同様に, 住宅の所有形態によって高齢者住宅のニーズ は異なると仮定し, 持ち家, 公的賃貸 (公営, 都市機構, 公社など), 民営賃貸の 3 種に住宅所有形態を類型化した。高齢者住宅への転居 に伴い家賃や生活支援サービス費が発生すること, 住宅のバリアフ リーの状況やバリアフリー改修の可能性が住宅の所有形態によって 異なること, 住宅の所有形態と所得には一定の関係性があることな ぞを踏まえ，この 3 類型とした。構成比は 2005 年の国勢調査デー夕 を用い, 将来的にわたってこの構成比が継続するものとして推計し た.

\section{(5)施設利用者数の減算}

(1)〜 (4)の手順に基づいて算出された高齢者数から，高齢者施設定 員数を減算する，高龄者施設の範囲は介護保険 3 施設, 認知症高齢 者グループホーム, 一般型特定施設とし, 要介護度 5 から順に施設

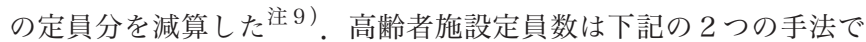
推計した。

\section{$\mathrm{a}$ ：第 4 期介護事業計画後の水準を保った場合}

2011 年度（第 4 期介護事業計画終了時）の調査対象自治体の高齢 者数に対する定員数割合を算出し，この割合が将来にわたて継続す ると仮定した場合の推計值. ただし調査調査自治体 A区では区外に 住民用として確保している特養 70 床を加味している。

$\mathrm{b}$ : 参酌標準によった場合

現在，国が示している参酶標準（要介護度 $2 \sim 5$ の認定者に対し て 37\%) を維持する場合の推計值.

\section{(6)対象高齢者数}

以上(1)〜 (5)の手順の結果, 対象高齢者数（要介護 1 以上の高齢者
数からその市町村で整備されている高齢者施設の床数を除した数) が明らかとなる。

\section{2 試算結果}

試算結果を図 3 に示す。前述の条件の組み合わせから (3) $\mathrm{a} \times(5) \mathrm{a}$, (3) $\mathrm{a} \times$ (5) b , (3) b × (5) a , (3) b × (5) b の 4 通りの結果を得た。

各グラフは上段から単身世帯，夫婦のみ世帯，その他世帯，施設 定員数を意味し，対高齢者人口割合で表わしている。それぞれの棒 グラフは左（色の濃い部分）から持ち家・公的賃貸・民間賃貸を表す.

一般に，その他世帯よりも単身世帯や夫婦のみ世帯で介護困窮度 が高いため施設入居割合が高いと推察される。よって, ここで示し た対象高齢者数は単身世帯と夫婦のみ世帯で過剩值，その他世帯で 過小值と考えられる。また, 前述したように調査対象自治体のデー 夕提供の制約上から， D市， E 市には誤差が生じていると推察され， この点を踏まえて試算結果を読み込む必要がある.

\section{3 異なる推計方法での試算結果の比較}

推計方法によって, 対象高齢者数と対象高齢者数比率（対象高齢 者数 / 高齢者数) には差異が生じている（表 4$)$ ，例えば $\mathrm{C}$ 市の「単 身のみ世帯」では，もつとも小さい推計值では $2.13 \%$ [世帯推計 $\times$ 参酌標準 ], もっとも大きい推計值では 3.83\% [(世帯推計 + 地域指標) $\times$ 第 4 期水準］と 1.80 倍の開きがあった.

そこで,「単身のみ世帯」の数值と, その数值を [(世帯推計+地 域指標）×参酶標準]を基準とした比率で表したものを表 2 のそれ ぞれの自治体の下段に示した。（世帯推計 + 地域指標 $) \times$ 参酌標準 $]$ よりも下方推計值が多く，C市の［世帯推計 $\times$ 参酌標準］が 0.57 と 最も小さな值となっている。一方，G市のように差異が小さい場合 もあり $(0.96 \sim 1.00)$, 算定方法によるばらつきが大きいことがわ かる. 同様の結果は「夫婦のみ世帯」や「その他世帯」でも確認で きた.

世帯推計は都道府県別の值であるため，調査対象自治体の值が都 道府県全体の傾向から外れた場合は誤差が大きくなる。（世帯推計+ 地域指標）は調査対象自治体における世帯構成の調査結果をもとに 都道府県単位での世帯推計による世帯数の推移推定（世帯構成比率 の増減）を加味しており，前者に比べて䛊差が少ないと考えられる.

以上のように異なる推計方法で 4 つの結果を得ているが，世帯指 標としては（世帯推計十地域指標）が適切と考える，高齢者施設整 備指標としては，[参酶標準]で統一することが望ましい，施設整備 割合の条件が同一となるため, 市町村間での高齢者住宅数を比較検 討するのに適しているからである注 10)。よって以下では，[（世帯推 計十地域指標） $\times$ 参酌標準]で記載を行う.

\section{4 世帯と住宅の状況を踏まえた高齢者住宅施策の必要性}

2025 年の対象高齢者数比率 (対象高齢者数 / 高齢者数) が最も低 いのはE市であるが，前述したとおりデー夕提供の制約から男女別 なし年齢階級別なしの要介護認定率を用いており，これを除くとい ずれの自治体も対象高齢者数比率は $9.19 \sim 11.87 \%$ に収まっている. これは, 各自治体における 2025 年の高齢者割合が近似してくること に加えて, 表 3 に示すように $\mathrm{A}$ 区のような都市部に比べて $\mathrm{G}$ 市のよ うな地方都市では要介護認定率（とりわけ後期高齢者）が高いこと による. 現時点での高齢化率は A 区・B市・C市・D市が $20 \%$ 前後, $\mathrm{F}$ 市・G市が $30 \%$ 弱（表 1 ） と著しく異なっていることから，地域 ごとに特性のある, 将来的な年齢階級ごとの人口動向，男女別年齢 


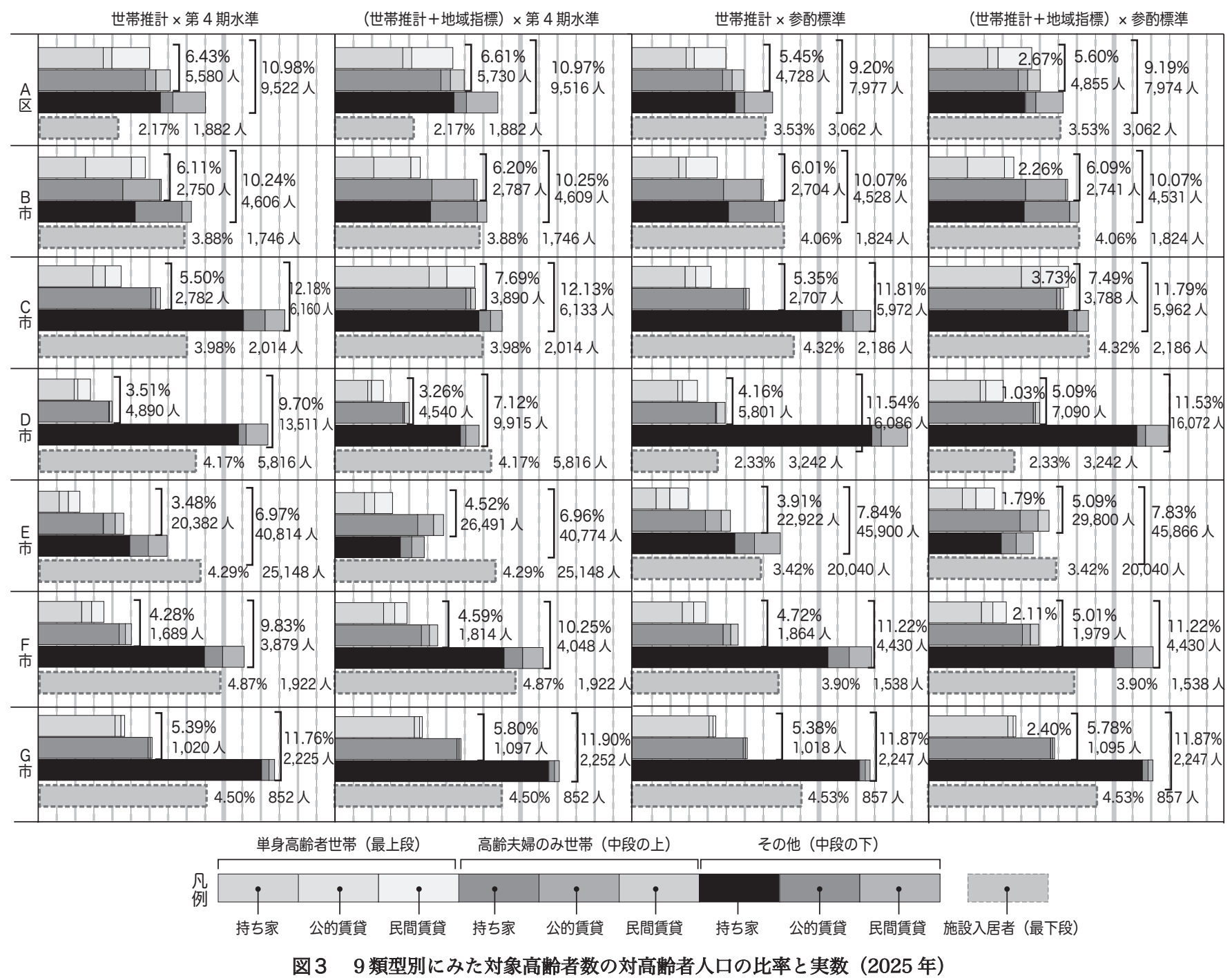

階級別の要介護度認定率等に留意し, 整備指針を立案することの重 要性が指摘できる。

世帯類型別にみると高齢者住宅に住み替える必要性が高いと考元 られる「単身世帯」の対高齢者人口比率は, A区・B市・C市のよ うな都市部よりも，F市や $\mathrm{G}$ 市のような地方のほうが低い傾向にあ るものの, 個別にみ水ば B市 : $2.26 \%, \mathrm{G}$ 市 : $2.40 \%$ とおおよそ等 しい（前述したようにD市と E 市はデー夕制約上の関係から考察の 対象としない). 図 3 からも明らかなように対象高齢者に占める単身 高歯者の割合は地方よりも都市部で高いため, 高㱓者住宅は都市部 の問題と考えられがちだが, 高齢者人口比でみれば変わらないこと に留意が必要だろう。

住宅の状況による違いも調査対象自治体で大きく異なる. 基礎デー 夕から, B 市では公的住宅の整備量が多く, 新たな高龃者住宅整備 よりも公的住宅での継続居住施策が重要な意味を帯びてくる，A区 では「民間賃貸」の比率が高いことに加えて「単身高齡者」の比率 も高く, 高齢者住宅ニーズは調査対象地域のなかでは最も高いと推 察される。これに対して, 地方都市に該当する $\mathrm{F}$ 市や $\mathrm{G}$ 市は「持ち 家」と「その他世帯」の比率の双方が高いことから, 高齢者住宅ニー ズはさほど高くないことが推測される. 対象高齢者数と参照すると, 「民間賃貸」，「単身高齢者」の割合が高いほど，そのニーズも高くな

表 4 異なる試算方法での算定結果の差異（単身世帯の場合）

\begin{tabular}{|c|c|c|c|c|c|}
\hline & & $\begin{array}{l}\text { 世帯推計 } \times \\
\text { 第4期水準 }\end{array}$ & $\begin{array}{c}\text { (世帯推計+ } \\
\text { 地域指標) } \times \\
\text { 第4期水準 }\end{array}$ & $\begin{array}{l}\text { 世帯推計 } \times \\
\text { 参酌標準 }\end{array}$ & $\begin{array}{c}\text { (世帯推計+ } \\
\text { 地域指標) } \times \\
\text { 参酌標準 }\end{array}$ \\
\hline \multirow{2}{*}{ A区 } & 対高齢者比率 (\%) & 2.97 & 3.16 & 2.51 & 2.67 \\
\hline & 比率* $* \%)$ & 1.11 & 1.18 & 0.94 & 1.00 \\
\hline \multirow{2}{*}{ B市 } & 対高齢者比率 (\%) & 2.81 & 2.30 & 2.76 & 2.26 \\
\hline & 比率* *\%) & 1.24 & 1.02 & 1.22 & 1.00 \\
\hline \multirow{2}{*}{ C市 } & 対高齢者比率 (\%) & 2.19 & 3.83 & 2.13 & 3.73 \\
\hline & 比率* $(\%)$ & 0.59 & 1.03 & 0.57 & 1.00 \\
\hline \multirow{2}{*}{ D市 } & 対高齢者比率 (\%) & 1.44 & 1.26 & 1.72 & 2.03 \\
\hline & 比率* $\left.{ }^{*} \%\right)$ & 0.71 & 0.62 & 0.85 & 1.00 \\
\hline \multirow{2}{*}{ E市 } & 対高齢者比率 (\%) & 1.19 & 1.59 & 1.34 & 1.79 \\
\hline & 比率 ${ }^{*}(\%)$ & 0.66 & 0.89 & 0.75 & 1.00 \\
\hline \multirow{2}{*}{ F市 } & 対高齢者比率 (\%) & 1.76 & 1.93 & 1.95 & 2.11 \\
\hline & 比率 ${ }^{*}(\%)$ & 0.83 & 0.91 & 0.92 & 1.00 \\
\hline \multirow{2}{*}{ G市 } & 対高齢者比率 (\%) & 2.32 & 2.41 & 2.31 & 2.40 \\
\hline & 比率* $(\%)$ & 0.97 & 1.00 & 0.96 & 1.00 \\
\hline
\end{tabular}

$*$ 比率は $[($ 世帯推計+地域指標 $) \times$ 参酌標準 $]$ を基準に算定

ると考えられる，以上，住宅の状況による違いを加味すると，都市 部での高齢者住宅ニーズは相対的に高いと言えよう.

なお， 2025 年の高齢者施設の整備数を参酌標準に合致させるた めには, 首都圏 $(\mathrm{A}$ 区・B市・ C 市 $)$ や三大都市圈（E市）では現 行の施設整備数では不足しており今後も量的整備が必要であること, 
表 5 各自治体の最低生活費の内訳（単身世帯の場合）

\begin{tabular}{|c|c|c|c|c|c|c|c|c|}
\hline & 該当エリア & 対象自治体の市場家賃 (a) & $\begin{array}{c}\text { 対象自治体を含んだ } \\
\text { 地域の高專賃家賃 (b) }\end{array}$ & $\begin{array}{l}\text { 対象自治体を含んだ } \\
\text { 地域の市場家賃 (c) }\end{array}$ & $\begin{array}{c}\text { 高齢者住宅家貨 } \\
\text { (a)+[(b)-(c)]=(d) }\end{array}$ & 生活扶助費** (e) & $\begin{array}{c}\text { 最低生活費 } \\
(\mathrm{d})+(\mathrm{e})\end{array}$ & 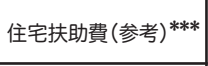 \\
\hline A区 & エリア 1 & 87,500 & 104,942 & 79,189 & 113,253 & 75,770 & 189,023 & 53,700 \\
\hline B市 & エリア2 & 54,400 & 89,906 & 55,445 & 88,861 & 75,770 & 164,631 & 53,700 \\
\hline C市 & エリア2 & 46,300 & 80,162 & 46,469 & 79,993 & 68,950 & 148,943 & 47,700 \\
\hline D市 & エリア3 & 47,500 & 82,400 & 52,800 & 77,100 & 68,950 & 146,050 & 32,000 \\
\hline E市 & エリア1 & 51,788 & 73,577 & 51,483 & 73,882 & 75,770 & 149,652 & 37,000 \\
\hline F市 & エリア2 & 42,900 & 55,100 & 41,100 & 56,900 & 65,870 & 122,770 & 32,000 \\
\hline G市 & エリア4 & - & 50,222 & - & $50,222 *$ & 59,170 & 109,392 & 26,600 \\
\hline
\end{tabular}

$*:$ 市場家賃が集計できなかったため高専賃家賃をそのまま使用注15) $, * *: 70$ 歳以上一人暮らしを想定, $* * *$ :生活保護費の住宅扶助特別基準額表より基準額を抽出 (円)
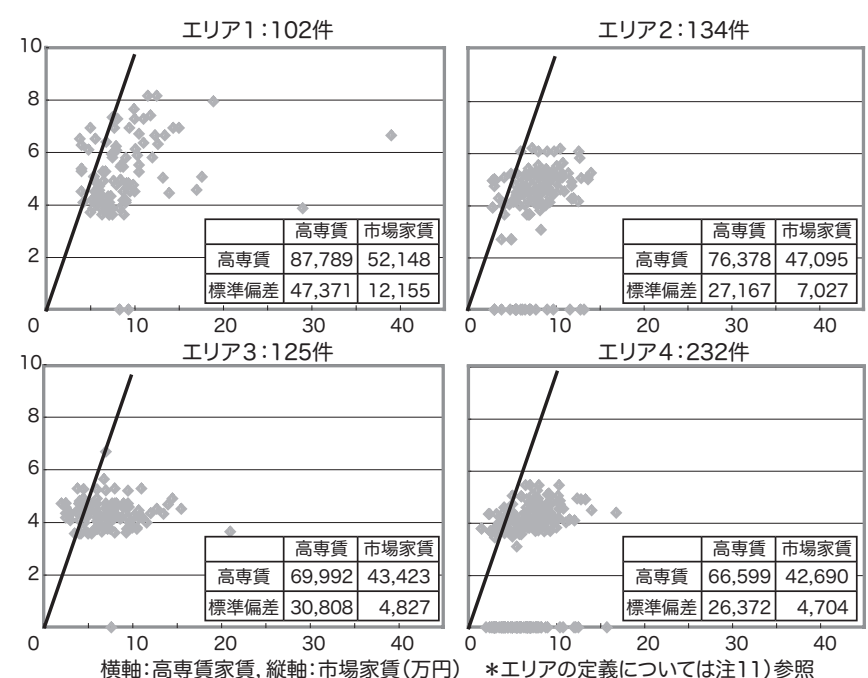

横軸: 高専賃家賃, 縦軸:市場家貨(万円) $*$ エリアの定義については注 11 )参照 エリア 3 :都道府県人口500万未満の都市部, エリア 4 ; 都道府県人口500万未満の都市部以外

図4 エリア別の高専貨家顀

一方で地方都市 $(\mathrm{F}$ 市・G市) では現行の施設整備数で充足してい ることがデータから読み取れる。

\section{4 高齢者住宅における最低生活費と支払い能力の算定手順と結果}

\section{1 算定手順}

調査対象自治体の高歯者住宅で生活する場合の月額費用（最低生 活費）を算出し，介護保険料算定時の所得段階デー夕をもとに利用 者の支払い能力を把握し, 両者の比較検討を行う。

\section{(1)最低生活費}

最低生活費 $=$ 高歯者住宅家賃 + 生活保護の生活扶助費と定義する. 図 4 に, 既報注 8 ) で明らかにしたエリア別の高専賃家賃（含む共 益費·管理費, 除く生活支援サービス費）の平均値, 市場家顀の平均值, 高専賃家賃と市場家債の分布状況を示す注 ${ }^{13)}$. ここからも分かるよ うに，例えばエリア1では高専賃家賃は市場家賃に比べて約 35,000 円，エリア 4 では約 24,000 円ほど高額であることわかる。これをも とに, 調査対象自治体の市場家賃に高専賃家賃との差額加えた額を 高齢者住宅家顀とした注 ${ }^{14)}$.

生活保護における生活扶助費は市町村によって額が異なる。最も 高い A 区と B 市で 75,770 円，最も低い $\mathrm{G}$ 市で 59, 170 円である，高 齢者住宅に転居した場合には，この生活扶助費で生活支援サービス 費, 食費, 介護保険 - 医療保険の保険料と自己負担, その他日常生 活費を賄うことが必要となる。生活支援サービス費は日中職員配置 で $1.0 \sim 1.5$ 万/月， 24 時間職員配置で $3.0 \sim 4.0$ 万/月が目安で あり, 食費は 4.0 万/月が目安となっている注 16$)$ 。よって, 生活扶
助費でこれらすべてを賄うことは理論的には極めて難しい．事業の 複合化・地域の互助の活用・介護保険の外部サービス利用型特定の 適用等により生活支援サービス費の低減が見込めること，自分で手 当てすることで食費の低隇が見込めることを念頭に, 生活保護の生 活扶助費を目安として採用している.

表 5 に, 調査対象 7 自治体の高齢者住宅における最低生活費（単 身世帯の場合）の試算結果を示す。参考までに, 表の最後に生活保 護における住宅扶助費を記載した。

(2)所得状況

対象自治体より介護保険料算定時の所得段階についてデー夕提供 を受けた，自治体によって分類の細かさが異なるため，国や都道府 県が分析に用いる枠組みに統一した。各段階の目安は以下の通り.

第 1 段階: 生活保護受給者および老齢年金受給者

第 2 段階：住民税非課税世帯，年金等収入 80 万円以下，国民年金層 第 3 段階：住民税非課税世帯．年金等収入 80 万円超 211 万円以下 第 4 段階：住民税課税世帯. 本人住民税非課税. よって, 単身世帯 はここには該当しない.

モデル厚生年金受給者の妻（専業主婦）が典型。

第 5 段階 : 本人住民税課税。本人の合計所得金額が 200 万円未満

例：公的年金収入 211 万円超 365 万円以下の者

第 6 段階：本人住民税課税。本人の合計所得金額が 200 万円以上

例：公的年金収入 365 万円超の者

なお，税制上，遺族年金は非課税所得となっており，収入がある にも拘わらず上記計算には組み込まれていないので留意が必要であ る.

\section{2 試算結果}

試算結果を図 5 に示す。介護保険料算定時の所得段階の分布, 高 歯者住宅での最低生活費を示した。

一月あたりの最低生活費は A 区で 189,023 円（年間 227 万）と最 も高く，G市で109,392 円（131 万）と最も低い. 全 7 自治体で比 較すると土地価格の高い首都圏ほど高く, 地方都市ほど低いことが 分かる. 表 3 からも明らかなように生活保護における生活扶助費の 違いよりも，高齢者住宅家賃の違いによるところが大きい.

単身で高齢者住宅で生活を行う場合, 年間収入の範囲内で最低生 活費が支払い可能な高歯者は A 区（年間 226 万）で第 5 段階以上， それ以外の 6 自治体（年間 131 万〜 198 万）は第 3 段階の半ば以上 となる。

\section{3 高齢者住宅への財政支援の必要性}

以上から，調査対象 7 自治体に限ってみ机ば，高専賃での最低生 活費を収入（フロー）で支払いできない者が，首都圈や県庁所在地 
$(\mathrm{A} \cdot \mathrm{B} \cdot \mathrm{C} \cdot \mathrm{D} \cdot \mathrm{E})$ では第 3 段階の後半まで, 地方都市 $(\mathrm{F} \cdot \mathrm{G})$ では第 3 段階の前半までが該当することが明らかとなった注 17 .

図 6 にも示したように, 高齢者住宅ニーズの高い単身世帯の所得 は厳しい状況にある 注 ${ }^{18)}$ 。もちろん, 所得で対応できない場合でも, 一定の資産（ストック）や家族による経済的支援が見込め机ば支払 い可能であり，資産の流動化を検討することがまずもつて必要とは なろう。資産に乏しい高齡者に対しては国や地方公共団体の財政的 支援が必要となる．高齿者住宅家賃は建設費補助と家顀補助の二通 りで低減可能となり, 低所得者をも対象とした高齿者施設や高㱓者 住宅, 例えば特別養護老人ホームや旧高優賃には双方が投入されて いる. どの自治体も特別養護老人ホームの整備には積極的であるが, 旧高優賃の整備に力を入れる自治体は極めて限定されている．福祉 政策ではなく住宅政策として位置づけられていること, 近年は公営 住宅の建設が抑制されていること, 家賃補助における自治体負担割 合が大きいことなどが影響しているものと思われるが，高齢者住宅 の整備促進には国や地方公共団体の財政支援が不可欠と判断される.

なお，図 5 のデー夕については以下のような課題がある。(1)所得 段階分布は 2009 年の現状值であり, 2025 年の分布の推計值が必要 である. (2)所得段階デー夕は住宅の状況別や世帯の状況別に整理す ることが必要である．高㱓者住宅のニーズが極めて高い単身世帯は 持ち家率が他の世帯類型よりも低いこと, 図 6 に示したように低所 得者が多いことなどが各種統計デー夕から明らかになっているため, この視点は極めて重要である，以上のことから，試算は議論をする 際の出発点としての基礎的試算にすぎず，各自治体の保有デー夕を もとにより詳細な試算や分析が必要と考える.

\section{5. 結論}

本研究では, 統計情報や将来推計等に基づいて, 2025 年時点で のサービス付き高歯者向け住宅を利用する可能性のある高龄者（対 象高歯者）数を算定し, 高齢者住宅整備量の試算根拠の導出手法を 試論として示した。あわせて高齢者住宅で生活した場合の最低生活 費を算出し，これを介護保険料算定時の所得段階のデー夕と比較す ることで，財政支援（住宅扶助や建設補助）すべき高齢者住宅数と 市場で整備可能な高齿者住宅数のバランスを検討した．高龃者住宅 の需要が高いとされる首都圈を中心に 7 つの自治体から協力を得て, 試算を行った.

対象高歯者の算定結果によれば，2025 年の対象高龄者は $10 \%$ 前 後に収斂していた（割合の低い E 市は統計データの制約によるもの と考えられるので検討から外している)，そのなかで高齢者住宅に住 み替える可能性が高いと考えられる「単身世帯」の対高齢者人口の 比率および該当者数は地域による差が大きく, 地域の実情を加味し た整備基準を自治体単位で策定することが必要であることが示唆さ れた。個別デー夕をみると，首都圈で単身・民間賃貸世帯など高齢 者住宅ニーズが高い者の割合が多いことが明らかとなり，地方都市 で同居・持ち家世帯など高齢者住宅ニーズが低い者の割合が多いこ とが分かった。

高歯者住宅での最低生活費と支払い能力に関する分析の結果，資 産 (ストック) を切り崩さない前提では, 首都圈と県庁所在地では 第 3 段階の後半まで, 地方都市では第 3 段階の前半までに対して, 国や地方公共団体による財政支援（建設費補助や家顀補助）が必要
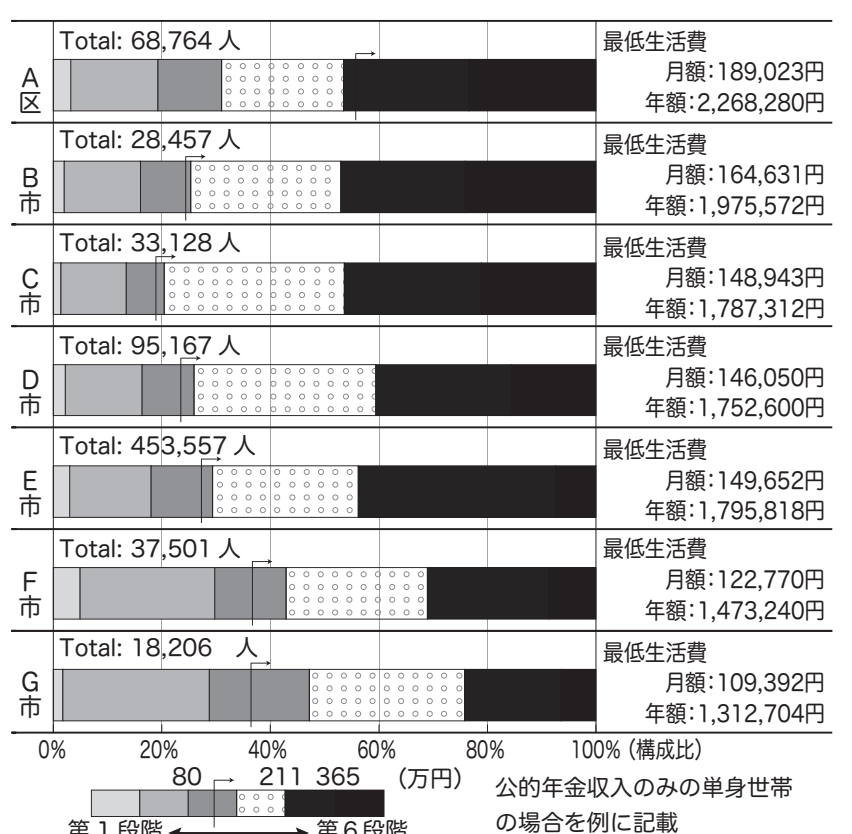

*グラフ中の矢印は, 所得段階の各段階内に一様に人数が分布していると仮定 した場合に, 右段の最低生活費の基準を超えるライン. なお, 第4段階は単身 世帯ではないので留意が必要である.

図 5 高齢者住宅における最低生活費と支払い能力

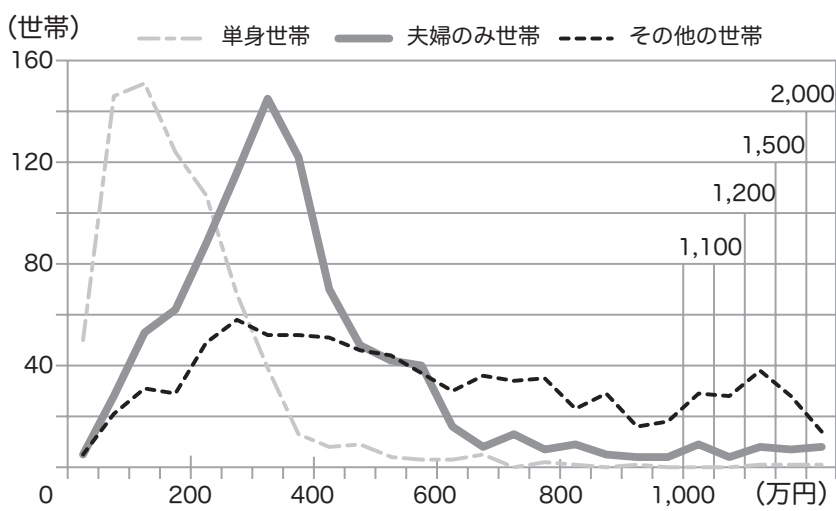

図6 高龄者のいる世帯の所得 (平成 19 年国民生活基礎調査)

であることが示唆された。高齢者住宅における利用者負担のあり方 について早急な検討が必要であろう。これと関連して新規建設され た高齢者住宅に転居するのではなく, 公的賃貸住宅等での継続居住 を前提に，それら既存住宅に生活支援サービスをどのように付加し てゆくかという視点を併せ持つことも重要と思われる.

なお今後の課題として以下が挙げられる。 まず第一に対象高龄者 数の精緻化が必要である. 住宅の状況, 世帯の状況についてトレン ドをふまえた推計が必要となろう。2 時間訪問介護看護など制度化 が予定されている新たな居宅サービスの進展に伴う影響も加味する 必要がある. 第二に実際に整備する住戸数の検討が必要となるが, この戸数は費用負担によって変化すると思われる。すなわち，高齢 者住宅への潜在的ニーズがあったとしても, 支払いが困難である場 合には，あるべきニーズが表出されない可能性がある。「整備すべき 戸数」と「整備する戸数」が近似することが望まれるが，それは利 用者の費用負担低減策等（住宅扶助，生活支援サービスの費用負担 低減の仕組み, 公営住宅や持ち家での継続居住策による転居ニーズ の抑制など）がどこまでなされるかに大きく左右されるものと推察 
される.この点を議論しない限り, 具体的な整備数を算出すること は困難である.

費用負担低減策を検討する際には，重度者向けの施設における住 宅扶助（補足給付と呼ぶ）との比較検討が欠かせない.介護人材の 有効活用のためには, 介護職員を多く必要とする施設は重度者向け に限定し, その前段階までを高齢者住宅もしくは自宅で受け止める ことが適切である。個室化やユニット化によって施設の居住環境や サービスが大幅に向上しつつある今日，住環境やサービスがそしい 故に個室が保障された高齢者住宅に留まるというロジックは成立し にくい. 高齢者住宅における最低生活費が, 施設に比べて低額であ るか，あるいは自宅に比べてさほど高額でないか，いずれかのメカ ニズムを成立させることが必要と考える．持ち家政策一辺倒できた 我が国において後者の実現は容易ではなく, 前者の実現を検討する ことが妥当であろう。しかしながら, 特別養護老人ホームなどの介 護保険施設では，一定の資産を有する層や家族による経済的援助が 期待できる層にまで補足給付が一律に適応されている。この点を改 善することと, サービス付き高齢者向け住宅の費用負担軽減策を検 討すること，両者を同時にすすめてゆくことが肝要と考える.

本研究は, 平成 20-21 年度厚生労働科学研究費補助金（政策科学 総合研究事業)「市場性を備えた良質な高齢者住宅の供給とケアサー ビスの附帯のさせ方に関する研究」(H20-政策 - 一般-005 研究代表: 井上由起子) の一環として行われた。

本稿は既報告（参考文献 17 ならびに 18）を再構成しているが, 既報において試算の一部に不備があり本稿において修正した。ここ に記してお詫びとする.

注

注 1 ) 平成 22 年度より高龄者等居住安定化モデル事業（厚生労働省・国土交 通省）において生活支援サービス付き高専賃に対して整備費補助が開始され た。また、高齢者住まい法の改正が検討されており、高円顀・高専賃・高優 賃を廃止し、有料老人ホームを含めて、サービス付き高㱓者向け住宅として 一本化することが議論されている。

注 2 ) 高齢者住宅に関する研究や書籍としては, 参考文献 1)～10) などがある. このうち, 参考文献 9）や参考文献 10）には住宅政策と福祉政策にまたがつ た提言がなされている。

注 3 ) 厚生労働省「第 2 回介護施設等の在り方に関する委員会」(平成 18 年 12 月 15 日) 資料 (http://www.mhlw.go.jp/shingi/2006/12/s1215-13. html）によると, 国によって高㱓者住宅の整備率が異なり, 海外の整備状 沉を参考に整備基準が算定できないことがわかる。

注 4 ）各自治体は介護保険事業計画に扔いて国から提示された参酶標準をもと に高齢者施設（介護保険施設, 特定施設, 認知症高齢者グループホーム) の 整備目標数を揭げている. 第 4 期介護保険事業計画では要介護度 $2 \sim 5$ の認 定者数あたり $37 \%$ となっている. 参酷標準の是非については議論が重叔ら れている。

注 5 ）本来であ机ば平山（参考文献 11)，12））のように, 高齢世帯の住宅保 有形態を分析すべきであるが，全国的な統計情報が整備されていないため, 国勢調査を基に 9 類型とした.

注 6 ）例えば平成 22 年 3 月にとりまとめられた地域包括ケア報告書では 2025 年におけるあるべき高齢者ケアの姿を提示するとともに，それに向け た課題を抽出している。 なお，この報告書では日常生活圈内に適切な住まい （自宅，高齢者住宅，施設）が確保されていることが前提条件であることが 明記されている。

注 7 ) 住宅の状沉（注 5 ）と同様に, 高齢者の詳細な資産状況を加味すべきで あるが，自治体からの情報提供が困難であることから，各自治体における介
護保険料算定時の所得デー夕を高齢者の所得状況として分析を行った。

注 8 ）参考文献 13）参照。この図 4 は 2008 年 6 月時点で登録済みの全国の 高専賃 (除く高優顀) デー夕を分析したものである。対象となる高専顀は 593 件.

注 9）1 章に記したように, 高齢者施設への転居は, 家族介護の負担の大きさ から住宅や世帯の状況に大きく左右されることなく中重度高齢者に一定の割 合で発生すると考元ら机ている。そのため，(4)までに算定された対象高齢者 の要介護度が高い順に, 各世帯から一様に施設定員分を減算した。要介護度 の途中に定員分の境界が位置する場合，各世帯の構成比により残りの定員分 を按分し，全ての世帯から減算をしている.

注 10）本研究の目的からは参酶標準が好ましいが，各市町村の高齢者住宅整 備戸数を具体的に検討する際には，その市町村の高齢者施設整備指針に基づ いた值を用いることが適切である，四国や九州を中心に参酶標準を大きく上 回る整備数に達している市町村が多数あり（いわゆる施設過剩地域）、こう いった地域は高秢者人口推計によっては施設数の抑制が必要となる。実態に 基づいた計画をたてるためには第 4 期水準での試算は欠かせないため、双方 の試算を実施した。

注 11) 例えば藤森 (参考文献 15) に上れば, 単身高路者が利用する介護保険サー ビスは掃除，食事の準備，買い物で上位 3 つを占めることが示されており， これらは高齢者住宅における生活支援サービスに合致している。また，厚生 労働省調査（参考文献 16）に上机ば，居宅で暮らす要介護認定を受けてい る単身高齢者のうち要介護 3 以上の割合は夫婦のみ世帯やその他世帯より少 なく, 多くの者が高齢者施設や家族同居へと生活の場を移していることが示 唆され，こういった高歯者はサービス付き高澮者向け住宅の必要性が高いと 総合的に判断できる.

注 12）エリア $1 \sim 4$ の分け方は以下の通り。都道府県人口 500 万人を境に都 道府県を「都市部」と「都市部以外」に分け，そのうえで県庁所在地と政令 指定都市の自治体を「指定都市」とし，それ以外の地域を「その他」とした 。詳細は参考文献 13)，14）を参照.

注 13）市場家顀とは高専顀が立地している周辺地域の賃貸物件の家顀（高専 賃と同等の広さと考元られる $1 \mathrm{~K} ， 1 \mathrm{R} ， 1 \mathrm{D} \mathrm{K}$ ) を全国の賃貸物件情報を 揭載している情報サイト HOME’sから収集し, 整理したものである。高専 貢家顀には共益費・管理費は含まれているが，生活支援サービス費は除かれ ている. 図4は，この結果を注 11）に示すように全国を人口規模などから 4つのエリアにわけ，まとめたものである．各図の右下には高専賃家顀と市 場家顀の平均值を記したが，高専賃家顀は標準偏差が大きいことに留意が必 要である。詳細は参考文献 13).

注 14）注 13 に記載したようにエリア別の高専賃家貢の標準偏差は極めて大き い. よって, 調査対象 7 自治体が該当するエリアの平均值をそのまま採用す ることは妥当でないと判断した。 そこで，まず対象自治体を含んだ地域の高 専顀家賃を算出した（自治体の高専賃数が少なく，そのなかに極めて高額な 高専貢が整備されているなどのケースがあるため範囲を広げて算出した). その値と同じ地域の市場家賃との差額を調査対象自治体の市場家梖に加算し た額を，対象自治体の高齢者住宅家兵とした。市場家顀は注 13）の算定方 法に基づいた市区町村別の平均家梖である.

注 15）G市においては，当該自治体の市場家賃，都道府県ごとの対象自治体 を含んだ地域の市場家顀の両者が欠損していた，そのため当該自治体が類さ れるエリア別高専賃家賃をそのまま採用した。

注 16) 例えば，日中職員配置 (9:00〜 17:00) では年 2920 時間となり，年 間労働時間 1600 時間 +1320 時間となる. 前者を正規職員 452 万円（給与 400 万，法定福利費 $13 \%$ ）+後者を 132 万円（時給 1000 円）とすると総 額で 584 万円となり,これを 40 戸の高専顀で負担すると 1.46 万/月となる. 夜間も同様に試算すると $3.0 \sim 4.0$ 万/ 月となる，食費は例えば特別養護老 人ホームの場合, 4.0 万が標準月額となっている。

注 17）本稿では, 最低生活費を高齢者住宅家債十生活扶助の額で定めている. その結果，家顀以外に年間 71 万〜 91 万円の生活費がかかり，第 1 , 第 2 段階の高齢者は高歯者住宅に住むことが不可能な前提となっている．注 16) で記載したように、一般的な高㱓者住宅に住んだ場合、生活支援サービス と食事にかかわる費用で月額で $5.46 \sim 8.00$ 万円がかかり、こ机に保険料、 1 割負担などを加味すると生活扶助額を超えることとなる。すなわち、低所 得者にとっては、たとえ家顀が発生しなくても、高齢者住宅に暮らすことは 経済的に困難を伴う。家賃扶助のみで解決しえない問題があることを指摘す 
るために、ここではあえて家顀十生活扶助で試算を行った。

注 18）高歯者のいる世帯の所得には、同居する高齢者以外の者の所得を含む。 その他世帯の所得には同居する子世帯の所得が含まれていることに留意が必 要である。

\section{参考文献}

1 ) 小野信夫 : 高齢者専用賃貸住宅の現状と課題 - 首都圈の高専賃登録データ から考える -, ニッセイ基礎研究所，ニッセイ基礎研 report No.126, pp. 19-26, 2007.9

2 ）松川修啓，鈴木義弘：高優顀及び高専顀の類型的把握と計画課題について, 日本建築学会研究報告九州支部, No.6, pp.109-112, 2007.3

3 ) 石井敏 : 入居者の居住実態からみた高齡者専用賃貸住宅のあり方に関する 事例考察，日本建築学会計画系論文集，No.627，pp.963-969，2008.5

4 ) 佐藤栄治, 井上由起子, 藤井賢一郎 : 高齢者専用賃貸住宅におけるサー ビス附帯と居住モデルに関する研究，日本建築学会計画系論文集，No.75, 651, pp.1035-1041，2010.5

5 ) 大塚武則, 藤井賢一郎, 白石旬子：サービス附帯から見た高龄者住宅の 特性に関する研究, 日本介護経営学会誌介護経営, Vol.4, No.1, pp.35-44, 2009.11

6 ) 園田眞理子 : 高龄者居住の現状と課題, 日本不動産学会誌, No.20-4, pp.67-72, 2007.5

7 ）山田雅之，武市千歩，山口健太郎，三浦研：高齢者専用賃貸住宅における 入居プロセス 自立高齢者を対象とした高齢者専用賃貸住宅に関する研究 (そ の 3), 日本建築学会大会学術講演梗概集，E-2，pp.243-244，2010.9
8 ）社団法人不動産協会 : 高龄社会における住宅のあり方に関する研究会報告 書, 2006

9 ) 平山洋介 : 住宅政策のどこが問題か, 光文社新書, 2009.3

10）広井良典：コミュニティを問いなおす，ちくま新書，2009.8

$11)$ 平山洋介：高龄世帯の住宅資産保有に関する階層分析, 日本建築学会計画 系論文集 No.75，652，pp.1549-1555，2010.6

12) 平山洋介 : 住宅・土地資産形成の変容に関する実態分析, 日本建築学会計 画系論文集 No.74，636，pp.431-438，2009.2

13）佐藤栄治，井上由起子，藤井賢一郎：高齢者住宅の整備状況をふまえた 家賃の現状分析，日本介護経営学会誌介護経営，Vol.4, No.1，pp.78-89, 2009.11

14）佐藤栄治，井上由起子，藤井賢一郎：高齢者専用賃貸住宅における家債の 市場性に関する考察 サービス附帯からみた高龄者住宅の特性と賃貸市場と の関連性に関する研究 その 2 , 日本建築学会大会学術講演梗概集，E-2, pp.251-252, 2009.9

15）藤森克彦：単身急増社会の衝撃，日本経済新聞出版社，2010

16）厚生労働省 : 国民生活基礎調査，2007

17）井上由起子，佐藤栄治，生田京子：統計情報に基づく高龄者住宅利用対 象者算定の一試案 市区町村単位別の高㱓者住宅需要の将来推計手法に関 する研究 その 1, 日本建築学会大会学術講演梗概集, E-1, pp.151-152, 2010.9

18）佐藤栄治, 井上由起子, 生田京子 : 所得分析と地域分析による高齢者住宅 利用対象者 市区町村単位別の高齢者住宅需要の将来推計手法に関する研究 その 2，日本建築学会大会学術講演梗概集，E-1，pp.153-154，2010.9

（2010年10月 9 日原稿受理，2011年 6 月 8 日採用決定） 